RAZGLEDI

\title{
VPRAŠANJE LEGITIMNOSTI SKUPNE KMETIJSKE POLITIKE Z VIDIKA OKOLJSKE KOMPONENTE TRAJNOSTNEGA RAZVOJA PODEŽELJA
}

\author{
AVTORICA \\ Maruša Goluža \\ Znanstvenoraziskovalni center Slovenske akademije znanosti in umetnosti, Geografski inštitut Antona Melika, \\ Gosposka ulica 13, SI - 1000 Ljubljana, Slovenija \\ marusa.goluza@zrc-sazu.si
}

DOI: $10.3986 / G V 86204$

UDK: 338.43.02:502.131.1

COBISS: 1.02

\section{IZVLEČEK}

Vprašanje legitimnosti skupne kmetijske politike z vidika okoljske komponente trajnostnega razvoja podeželja Trajnostni razvoj podeželja je postal eden glavnih ciljev skupne evropske kmetijske politike (SKP). Zaradi ukrepov, ki temeljijo na prostovoljnem sodelovanju kmetov, je uresničitev ciljev močno odvisna od kmetov in njihove okoljske zavesti. Nekatere raziskave kažejo na relativno majhen delež kmetov, ki se za izvajanje okolju prijaznih kmetijskih praks odločijo izključno na podlagi odgovornosti varovanja okolja in s doprinosom k trajnostnemu razvoju podeželja. Kmetje, čeprav glavni uporabniki SKP, veljajo za kritike SKP, saj le-ta ne rešuje povsem njihovih težav. Nezaupanje $v$ SKP kaže na pomanjkanje legitimnosti, česar se zaveda tudi Evropska unija. Rešitev, ki bi lahko rešila ta izziv, je vključevanje participativnega procesa v postopke odločanja in oblikovanja politik.

\section{KLJUČNE BESEDE}

trajnostni razvoj, skupna kmetijska politika, podeželje, legitimnost, participativno planiranje, varovanje okolja

\section{ABSTRACT}

The issue of CAP legitimacy in terms of the environmental component of sustainable rural development Sustainable rural development has become one of the main objectives of the common European agricultural policy (CAP). Due to the voluntary nature of CAP's measures, its success strongly depends on farmers environmental awareness. Some studies indicate a relatively limited share of farmers whose decisions to implement environmentally friendly agricultural practices are made solely on the basis of their moral duty to contribute to the sustainable rural development. Despite the main beneficiaries of the CAP, farmers strongly criticize the policy, which does not tackle their problems entirely.

Farmers' mistrust in the CAP reveals the lack of legitimacy, which has already been recognized by the European Union. The solution which could solve this challenge is the implementation of a participatory process in policy making.

\section{KEY WORDS}

sustainable development, common agricultural policy, rural areas, legitimacy, participatory planning, environmental protection

Uredništvo je prispevek prejelo 30. junija 2014. 


\section{Uvod}

Trajnostni razvoj je v zadnjih desetletjih postal zelo pomemben cilj razvoja družbe, kar se odraža $\mathrm{v}$ razvojnih dokumentih in politikah na vseh ravneh, od nadnacionalne do lokalne ravni. Trajnostni razvoj kot cilj se pojavlja na najrazličnejših področjih, kot so gospodarstvo, izobraževanje, okoljevarstvo, sociologija in druga. Tudi Evropska unija (EU) si vse bolj prizadeva vključiti trajnostno paradigmo v svoje sektorske politike, pri čemer skupna kmetijska politika (SKP) ni izjema. Ker SKP temelji na osebnih odločitvah kmetov, je dejanska možnost za uresničitev cilja trajnostnega razvoja SKP odvisna predvsem od njih samih. Pri tem se postavlja vprašanje same legitimnosti politike, ki je odvisna predvsem od tega, kako kmetje kot njeni glavni uporabniki sprejemajo oziroma dojemajo SKP in v praksi izvajajo ukrepe, ki naj bi spodbujali trajnostni razvoj podeželja.

SKP je vseskozi doživljala spremembe, tako vsebinske kot strukturne. Finančne spodbude so povzročile povečanje intenzivnosti kmetijstva, kar je na eni strani izboljšalo produktivnost evropskega kmetijstva, na drugi pa povzročilo številne negativne okoljske posledice. Skladno s svetovnimi trendi se je tudi v SKP sčasoma začelo uveljavljati načelo trajnosti. Do danes sta postala skrb za okolje in trajnostni razvoj podeželja dva izmed temeljnih (normativnih) ciljev SKP, ki se odražata tudi v sami strukturi politike. Le-ta temelji na sistemu dveh »stebrov«. Prvega sestavljajo neposredna plačila, ki jih EU izplačuje glede na hektar kmetijskih zemljišč, neodvisno od količine pridelka, drugega pa sredstva, namenjena razvoju podeželja.

V prispevku bomo izpostavili enega pomembnejših izzivov, s katerimi se sooča SKP, vprašanju njene legitimnosti z vidika okoljske komponente trajnostnega razvoja podeželja. SKP kmetom pripisuje poglavitno odgovornost za ohranjanje kmetijstva, doseganje okoljskih ciljev in trajnostni razvoj podeželja, vendar pa nezanimanje kmetov za izvajanje okoljskih ukrepov, opuščanje kmetijstva in izgubljanje značilnih evropskih kulturnih pokrajin, kljub finančnim spodbudam, kažejo prav na pomanjkanje legitimnosti politike. Kot eno izmed možnosti za večje odobravanje SKP in politik na splošno, predlagamo sodelovanje (participacijo) čim širšega kroga deležnikov v postopkih oblikovanja politik. Z upoštevanjem in usklajevanjem različnih interesov je mogoče doseči večjo legitimnost politike, hkrati pa tudi večjo uspešnost pri doseganju ciljev trajnostnega razvoja.

Način odločanja kmetov oziroma motivacija kmetov za izvajanje okolju prijaznih kmetijskih praks je pomembna sestavina in eden izmed pogojev za uspešnost SKP. Iz tega, kako kmetje sprejemajo okoljske cilje SKP, izhaja tudi vprašanje njene legitimnosti. Čeprav bi tovrstne raziskave pripomogle k večji učinkovitosti SKP, je to področje sprejemanja okoljskih ciljev SKP med kmeti še vedno precej slabo raziskano, tako v Sloveniji kot v EU. V Sloveniji raziskav $\mathrm{z}$ omenjenega področja še ni bilo, ali pa njihovi rezultati še niso bili objavljeni. V prispevku se zato opiramo predvsem na raziskave tujih avtorjev iz različnih držav EU, ki so do rezultatov prišli na podlagi intervjujev kmetov v preučevanih regijah.

\section{Trajnost in trajnostni razvoj}

Trajnostni razvoj je v zadnjih desetletjih postal zelo pomembna tema ter cilj različnih strategij in drugih razvojnih dokumentov. Izpostavljen je bil v številnih svetovnih političnih dokumentih, kot so Brundtlandino poročilo (Report ... 1987), deklaracija iz Ria (The Rio ... 1992), Agenda 21 (1992), Johannesburška deklaracija (Johannesburg ... 2002) in drugi. Zaradi zelo pogoste uporabe pojma trajnostni razvoj v strokovni in poljudni literaturi ter v medijih lahko dobimo vtis, da je razlog njegove uporabe zgolj popularnost in ne njegovo razumevanje ter želja po trajnostnem razvoju družbe.

Becker (2012) v pojmu trajnost združuje tri vidike: neprekinjenost, usmeritev razvoja ter odnose. Trajnost $\mathrm{z}$ vidika neprekinjenosti pomeni zmožnost nadaljevanja, vzdrževanja ali obstoja nečesa v določenem stanju skozi čas. Razložimo jo lahko kot sposobnost sistema, da se vzdržuje, nadaljuje ali pa kot sposobnost ljudi, da vzdržujejo določen sistem. Druga komponenta trajnosti je normativna in predstavljanekaj zaželenega, ideal, h kateremu bi kot družba morali stremeti. Trajnost v tem pogledu pojmujemo 
kot usmeritev dolgoročnega delovanja družbe, kar pogosto zasledimo v izjavah politikov v povezavi s trajnostjo. Tretji vidik, kot nepogrešljiv sestavni del celovitega pojmovanja pojma trajnosti, $v$ ospredje postavlja odnose. Avtor izpostavlja tri vrste odnosov: poleg odnosa družbe do trenutno živeče družbe in do prihodnjih generacij, še njen odnos do narave. Na podlagi teh treh vidikov isti avtor trajnost opredeli kot sposobnost vzpostavitve neprekinjenosti kot sredstva za usmeritev družbenih dejavnosti v smeri trojne povezanosti družbe: sodobne družbe, prihodnjih generacij in narave (Becker 2012).

Trajnostni razvoj, kot želena usmeritev prihodnjega razvoja družbe, torej pomeni tako usmeritev prostorskega, gospodarskega in regionalnega razvoja, ki spoštuje omejitve okolja oziroma pokrajine. Obsega tako razvoj poselitve, gospodarstva, infrastrukture in pokrajinske rabe kot tudi varstvo bivalnega okolja, naravnih virov ter ohranjanje pokrajinske, ekosistemske in vrstne pestrosti. Pri trajnostnem razvoju gre torej za okolje- in naravovarstveno sprejemljivo stopnjo ter obseg antropogene preobrazbe okolja. Prilagojen mora biti tako geografski edinstvenosti kot tudi razvojnim možnostim in omejitvam prostora. Prav tako mora upoštevati lokalno kulturo in obstoječe družbene (socialne) norme, vključno s krajevno značilno rabo zemljišč, lokalno oblastjo, vero ... (Plut 2010).

V zadnjih desetletjih tudi EU vse pogosteje vključuje trajnostno paradigmo v svoje sektorske politike, tudi vSKP. Možnost za uresničitev okoljskih ciljev SKP je vprašljiva predvsem iz dveh razlogov: deloma zato, ker je SKP omejena le na določen sektor, kmetijstvo, deloma pa zato, ker večina ukrepov politike temelji na spodbudah. Sodelovanje kmetov oziroma njihovo sprejemanje okoljskih ukrepov je odvisno od osebnih odločitev in torej prostovoljno (Baldock, Dwyer in Sumpsi Vinas 2002).

\section{Razvoj trajnostne paradigme v SKP}

SKP je v svoji skoraj šestdesetletni zgodovini doživela številne spremembe. Sprva je skušala doseči pravične dohodke kmetijskih gospodarstev, s čimer bi zagotovili gospodarsko in socialno enakopravnost kmetijskega z ostalimi sektorji. V skladu s splošnimi trendi je kmalu tudi v SKP začela vedno bolj izstopati trajnostna paradigma. Danes je trajnostni razvoj postal eden njenih glavnih ciljev in, vsaj na normativni ravni, vse bolj poudarja varstvo okolja in trajnostni razvoj, vključno z večnamenskostjo kmetijstva ter skupnimi interesi kmetov in ostalimi prebivalci.

\subsection{SKP kot sektorska politika}

SKP je ena najstarejših skupnih, nadnacionalnih politik v Evropi po drugi svetovni vojni. Vzpostavljena je bila leta 1957 z Rimsko pogodbo v takratni Evropski gospodarski skupnosti, ki jo je sestavljalo šest držav ustanoviteljic: Belgija, Francija, Italija, Luksemburg, Nemčija in Nizozemska (Medmrežje 1). Nastanek SKP je v največji meri rezultat dveh takrat poglavitnih političnih ciljev (Petrick 2008):

- premostitev nacionalnih ovir pri trgovanju s kmetijskimi pridelki v Evropi in

- reševanje temeljnega strukturnega problema evropskega kmetijstva - nizke produktivnosti kmetijstva in delovne sile.

S tema dvema ciljema sta bili neposredno povezani tudi vprašanji prehranske varnosti in naraščajočih razlik v dohodkih kmetov v primerjavi $\mathrm{z}$ dohodki zaposlenih $\mathrm{v}$ ostalih panogah (Petrick 2008).

Z Rimsko pogodbo je bilo določenih pet temeljnih ciljev SKP (The Treaty ... 1957):

- povečati kmetijsko produktivnost s pospeševanjem tehničnega napredka in zagotavljanjem racionalnega razvoja kmetijske proizvodnje ter z optimalno uporabo proizvodnih dejavnikov, zlasti delovne sile;

- zagotoviti primerno življenjsko raven kmečkega prebivalstva, zlasti s povečanjem individualnega zaslužka kmetov;

- stabilizirati trge;

- zagotoviti redno preskrbo s hrano in

- zagotoviti, da je preskrba s hrano potrošnikom dostopna po primernih cenah. 
Kmetijstvu je bil priznan tudi poseben status, ki izvira iz njegove specifične socialne strukture ter strukturnih in naravnih neskladij med različnimi kmetijskimi regijami (The Treaty ... 1957). SKP je sprva spodbujala kmetijsko proizvodnjo s sistemom vzdrževanja visokih cen pridelkov domačih pridelovalcev $\mathrm{v}$ kombinaciji z visokimi izvoznimi podporami. $\mathrm{V}$ šestdesetih letih 20 . stoletja so vzpostavili prost pretok kmetijskih pridelkov znotraj Skupnosti, odpravili carine, poenotili cene kmetijskih pridelkov ter uvedli še nekatere druge ukrepe (Medmrežje 2).

V sedemdesetih letih 20. stoletja je prišlo do prve krize SKP zaradi naraščajočih presežkov določenih kmetijskih pridelkov in hitro naraščajočih stroškov politike. Evropska komisija se je odločila zmanjšati stroške s spodbujanjem kmetov k opustitvi kmetijstva. Na ta način naj bi se prosta kmetijska zemljišča prerazporedila, kar naj bi pripomoglo k povečanju obstoječih kmetij, večje površine kmetijskih zemljišč pa naj bi prispevale $\mathrm{k}$ večji donosnosti in boljši primerljivosti dohodkov v kmetijstvu $\mathrm{z}$ drugimi panogami. Kmetijska skupnost je te predloge zavrnila; v reformi leta 1972 pa so bile sprejete le tri direktive: spodbujanje posodobitve kmetijskih gospodarstev, spodbujanje zgodnjega upokojevanja kmetov in strokovno izobraževanje kmetov. Tri leta kasneje so začele spodbude za ohranjanje kmetijstva dobivati tudi kmetijska gospodarstva v manj ugodnih razmerah za kmetijstvo (na primer v hribovitih območjih). Zaradi presežkov so bile določene tudi kvote za določene pridelke in kazni v primeru preseganja le-teh (Medmrežje 3).

\subsection{Začetki uveljavljanja pomena varstva okolja v SKP}

Čeprav je bila SKP z vidika samooskrbe držav članic uspešna, se je EU še vedno spopadala s presežki določenih pridelkov. Nekatere od teh so zato ob znatni podpori subvencij izvažali, druge pa skladiščili in prerazporejali znotraj Skupnosti. Ukrepi SKP so pomenili ogromen strošek, poleg tega pa so vplivali tudi na svetovne trge in niso vedno koristili pridelovalcem (Medmrežje 4). SKP je z dohodkovnimi podporami koristila predvsem največjim in najbolj intenzivno usmerjenim kmetijam, manj pa veliki večini majhnih in srednje velikih kmetij. Dohodki kmetov so se od leta 1975 do 1989 zvišali le malenkostno, stroški SKP pa so vseeno naraščali, čeprav se je v istem obdobju kmečko prebivalstvo v Evropski gospodarski skupnosti zmanjšalo za kar $35 \%$. Izkazalo se je, da ukrepi SKP niso bili najbolj uspešni, niti niso izpolnili ciljev, določenih z Rimsko pogodbo. Leta 1989 je bila več kot polovica evropskega kmečkega prebivalstva starejša od 55 let, prihodki kmetov v različnih državah članicah pa so se razlikovali tudi za trikrat. Tretjina kmetov je bila le delno zaposlena v kmetijstvu, kmetijska gospodarstva pa so se po velikosti močno razlikovala (velikosti so se gibale med 4 in 65 ha) (The Development... 1991). Ukrepov SKP niso podpirali ne potrošniki, ne evropski davkoplačevalci (Medmrežje 4), kar je pomenilo nujnost sprememb politike.

Proti koncu osemdesetih let 20. stoletja je trajnostna paradigma začela izpodrivati paradigmo pravičnosti. Te spremembe so spodbudile nekatere okoliščine:

- Kljub SKP je število zaposlenih v kmetijstvu upadalo, zmanjšal pa se je tudi delež kmetijstva v celotnem gospodarstvu.

- S povečanjem okoljskih posledic industrijskega, intenzivnega načina pridelave se je predvsem med mestnim prebivalstvom vse bolj uveljavljala zavest o vrednosti podeželja in njegovih okoljskih storitev. V tem obdobju se je že začelo povečevati tudi zanimanje za ekološko kmetovanje. Pogovorom o prihodnosti SKP se je pridružila nova skupina deležnikov, ki so zagovarjali varstvo okolja in pravice potrošnikov. Mnogi so SKP označili kot gonilo neprimernega varstva narave, uničevanja značilnih podeželskih pokrajin in obremenjevanja okolja $\mathrm{z}$ nevarnimi snovmi.

- Zagotavljanje enotnega trga za kmetijske proizvode, ena glavnih nalog dotedanje SKP, je postalo nepotrebno zaradi uvedbe skupnega evropskega trga, uvedenega z Enotnim evropskim aktom (1987) in kasneje še z Maastrichtsko pogodbo (Pogodba o ... 1993).

- Pričakovana širitev EU in povečanje števila kmetijskih gospodarstev, bi pomenila nesprejemljiv strošek SKP, če bi še naprej ostala v takšni obliki, kot je bila (Petrick 2008). 
Konec osemdesetih let se je ideja o širšem pojmovanju koristnosti kmetijstva za podeželska območja preselila tudi v uradne evropske dokumente. Tako je na primer evropska komisija v eni izmed tako imenovanih zelenih knjig leta 1985 (Perspectives ... 1985) in v dokumentu Prihodnost podeželske družbe (The Future ... 1988) poudarila, da bi moral biti razvoj podeželja samostojni cilj SKP in ne le stranski produkt kmetijstva.

Leta 1992 je SKP s tako imenovano MacSherryjevo reformo doživela ponovno večjo spremembo. $S$ to reformo se je zgodil premik s spodbujanja produktivnosti (z vzdrževanjem visoke ravni cen pridelkov) $\mathrm{k}$ podporam proizvajalcev (dohodkovnim podporam kmetom). Cilj reforme je bil na eni strani dvigniti konkurenčnost kmetijstva, stabilizirati kmetijske trge, povečati raznovrstnost pridelkov in varovanje okolja, na drugi strani pa stabilizirati izdatke, ki jih EU namenja SKP (Medmrežje 5). Cilj MacSherryjeve reforme je bil zmanjšanje cenovnih podpor za kmetijske pridelke in ta sredstva nameniti drugim ukrepom, ki ne bi spodbujali produktivnosti in bi jih kmetom izplačevali neposredno, glede na hektar kmetijskih zemljišč ali na žival (Reform ... 1991; Petrick 2008).

Smernice za novo SKP so bile (The Development... 1991):

- zmanjšati presežke pridelkov ter uskladiti pridelavo in povpraševanje;

- bolj upoštevati dohodkovne težave, s katerimi se soočajo manjša kmetijska gospodarstva;

- podpirati kmetijstvo v tistih regijah, ki so pomembne z vidika doseganja skladnega regionalnega razvoja, vzdrževanja socialnega ravnovesja in varovanja okolja ter

- povečati okoljsko osveščenost med evropskimi kmeti.

Ukrepi SKP po MacSherryjevi reformi so imeli dva temeljna cilja (The Development ... 1991):

1. Ohraniti zadostno število evropskih kmetov, saj je to edini način za ohranjanje tradicionalne pokrajine in na družinskih kmetijah temelječega modela kmetovanja. To zahteva aktivno politiko razvoja podeželja, katere pa ni mogoče izvajati brez kmetov.

2. Razširiti spoznanje, da je prav kmet tisti, ki ustvarja in ohranja okolje in prispeva k razvoju podeželja. Več pozornosti je treba nameniti tudi nematerialnim storitvam, ki jih opravljajo kmetje. Z vidika varovanja okolja je pomembna njihova vloga pri upravljanju z okoljem prek bolj ekstenzivne rabe kmetijskih zemljišč in izvajanja okolju prijaznih kmetijskih praks.

Kljub težnjam po njihovi popolni ukinitvi je SKP le zmanjšala plačila za posamezne pridelke. Izpad teh dohodkov je bil kmetom izplačan z zneski, katerih višina je bila določena glede na hektar kmetijskih zemljišč ali število glav živine. Uvedeni so bili tudi določeni kmetijsko-okoljski ukrepi, ki so spodbujali manj intenzivno kmetijstvo (Promoting ... 1998). Ukrepi so bili sicer dobro sprejeti tako v javnosti kot med kmeti, vendar slednjih niso spodbudili v zadostni meri, da bi se prostovoljno odločali za okolju bolj prijazne kmetijske prakse (Agenda ... 1997).

\subsection{Uveljavitev cilja trajnostnega razvoja podeželja v SKP}

Prvi dokument, ki je nakazal korenito spremembo SKP, je bilo tako imenovano Buckwellovo poročilo (Towards ... 1997), ki je izpostavilo, da bi morala SKP temeljiti na uravnoteženosti treh ključnih temeljev: učinkovitem kmetijstvu, okoljski trajnosti in razvoju podeželja. Poleg tega je poročilo zagovarjalo tudi idejo, da bi morali biti (finančni) ukrepi popolnoma neodvisni od produktivnosti (Towards ... 1997). Z Amsterdamsko pogodbo (1999) so se v SKP dokončno uveljavili cilji trajnostnega razvoja, ki so združevali gospodarske, družbene in okoljske cilje. Vzpostavljen je bil drugi steber SKP, ki je zagotavljal ločena sredstva, namenjena trajnostnemu razvoju podeželja (Promoting ... 1998).

Poleg osnovnih ciljev SKP (pravičen življenjski standard evropskih kmetov in stabiliziranje prihodkov kmetijskih gospodarstev) so postajala vedno bolj pomembna vprašanja družbene integracije, trajnostnega načina kmetovanja, integracije okoljskih ciljev v SKP ter priznavanje vloge kmetov kot upravljavcev pokrajine in naravnih virov. Pomemben cilj za prihodnost SKP je bil tudi ustvarjanje dodatnega zaslužka in zaposlitvenih možnosti za kmete in njihove družine na sami kmetiji ali pri drugih dopolnilnih dejavnostih. Izpostavljena je bila tudi večnamenskost podeželja, na podlagi katere naj bi kmetije skušale čim bolje izkoristiti priložnosti za razvoj podeželskega podjetništva (Agenda ... 1997). 
Leta 2003 je v SKP prišlo do štirih večjih sprememb (CAP ... 2003):

- Uvedba sheme enotnih plačil; plačila kmetom so postala neodvisna od količine in vrste pridelka, s čimer naj bi kmetje postali bolj tržno usmerjeni in motivirani za izkoriščanje svojih podjetniških potencialov. Neposredna plačila so povezali s tako imenovano navzkrižno skladnostjo, ki naj bi kmete spodbudila k ohranjanju kmetijskih zemljišč in upoštevanju določenih okoljskih zahtev.

- Obvezno upoštevanje navzkrižne skladnosti; določenih je bilo 18 standardov s področja varovanja okolja, prehranske varnosti in dobrobiti živali. V primeru neupoštevanja teh zahtev so bile določene tudi kazni.

- Prerazporeditev sredstev SKP v prid ukrepom za razvoj podeželja; s tem ukrepom so prerazporedili določen delež sredstev, namenjenih neposrednim plačilom za razvoj podeželja.

- okrepitev pomena politike razvoja podeželja; ukrep je bil namenjen predvsem izboljšanju kakovosti kmetijskih pridelkov, doseganju večje okoljske osveščenosti, svetovanju kmetom in skrbi za dobrobit živali.

V zadnjih letih so ponovno potekala pogajanja za novo programsko obdobje (2014-2020). SKP bo še vedno temeljila na sistemu dveh stebrov, s katerima skuša doseči konkurenčnost ter trajnostni razvoj kmetijstva in podeželja. Prvi steber temelji na delovanje kmetijskih trgov in oskrbne prehranske verige ter na neposrednih plačilih, ki so pogojena $z$ navzkrižno skladnostjo. Ukrepi prvega stebra naj bi zagotavljali osnovo za trajnostno kmetijstvo v EU. Drugi steber obsega ukrepe, ki so usmerjeni k izboljšanju konkurenčnosti kmetijskega sektorja, zagotavljanje vzdrževanja pokrajine kot javne dobrine, spodbujanje raznovrstnosti gospodarske strukture na podeželju in izboljšanje kakovosti življenja na podeželskih območjih (krajše - ukrepi za razvoj podeželja) (European Union ... 2014). Vzdrževanje pokrajine je pomemben vidik trajnostnega razvoja podeželja, zato SKP z različnimi ukrepi skuša doseči ohranitev podeželskih pokrajin ter kmete postavlja v vlogo upravljavcev pokrajine in njenih okoljskih

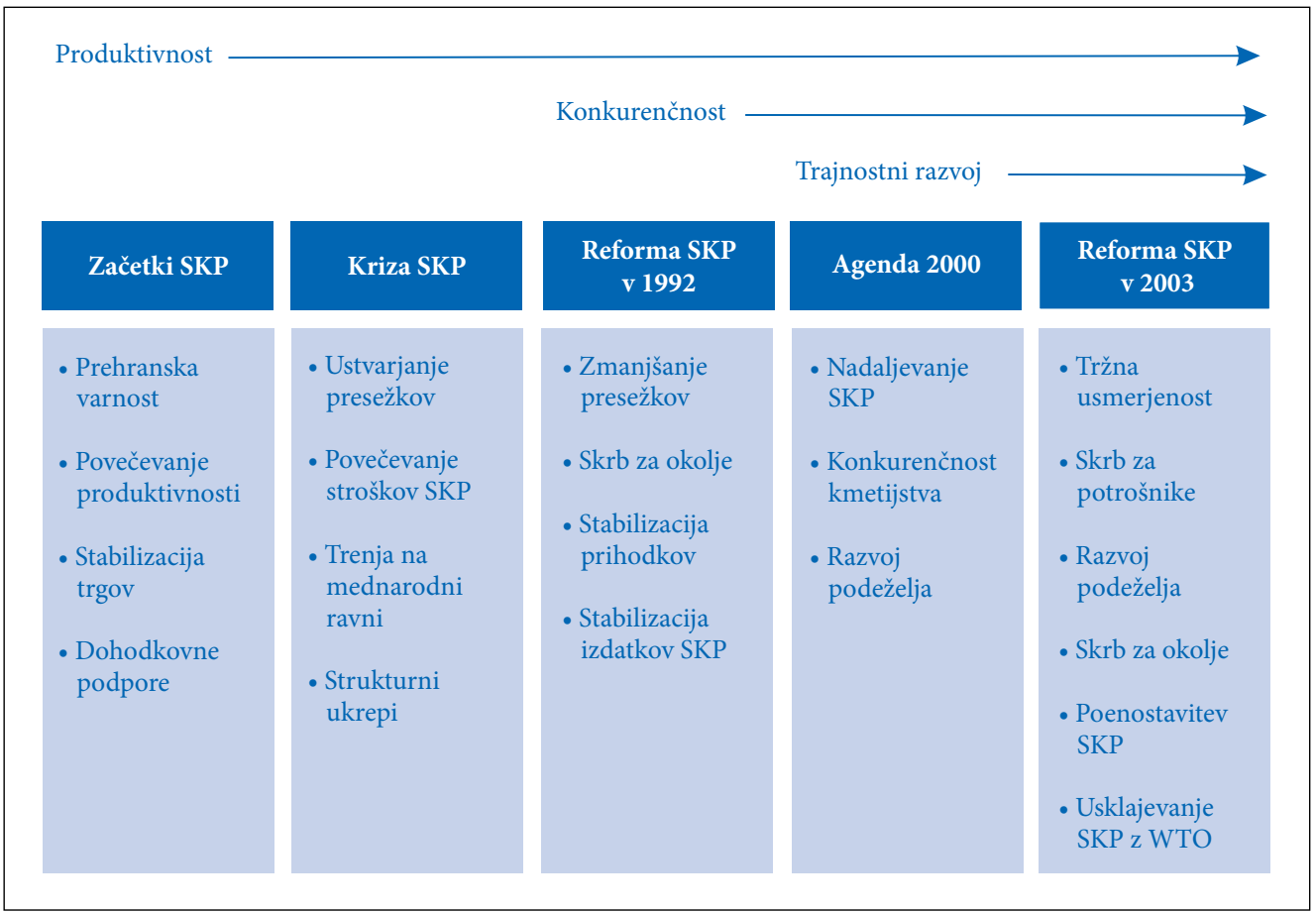

Slika 1: Razvoj skupne kmetijske politike (Agricultural ... 2011). 
dobrin (Van Herzele s sodelavci 2013). Ti ukrepi so prostovoljni, vezani na pogodbe, sofinancirani pa so s strani držav članic in zato tudi usklajeni na različnih ravneh (od evropske do lokalne). Na ta način je vsaj v določeni meri zagotovljena prilagojenost regionalnim oziroma lokalnim potrebam držav članic. Kombinacija izvajanja ukrepov iz obeh stebrov naj bi ustvarjala kmetijsko politiko, ki združuje neposredno podporo s točno usmerjenimi cilji in dosega zadostno razširjenost ukrepov, da so učinki razpoznavni na evropski ravni (European Union ... 2014).

\section{Legitimnost SKP z vidika okoljske komponente trajnosti}

SKP je skupna celotni EU, kar pomeni, da evropsko podeželje na nek način enači. Predvsem prvi steber z neposrednimi plačili ne upošteva lokalnih posebnosti držav ali regij znotraj njih, medtem ko imajo države članice nekoliko večjo vlogo pri določanju ukrepov v drugem stebru, namenjenemu razvoju podeželja. SKP temelji na povsem prostovoljnem sodelovanju in osebnih odločitvah kmetov. To pomeni, da se kmetje sami odločajo, katere ukrepe bodo upoštevali (če sploh) in seveda tudi to, v kolikšni meri bodo upoštevali okoljska določila. Za sledne ne zadostuje le okoljska zavest, ki je sicer pogoj za okoljsko odgovorno vedenje. Delovanje človeka v okolju je v veliki meri odvisno tudi od obsega ovir, stopnje motivacije in navad, ki vplivajo na dejansko vedenje (Polajnar Horvat 2012). Čeprav SKP kmetom nalaga glavno odgovornost za ohranjanje kmetijstva, doseganje okoljskih ciljev in trajnostni razvoj podeželja, je bilo narejenih relativno malo raziskav, s katerimi bi ugotovili način odločanja kmetov glede izvajanja okolju prijaznih kmetijskih praks.

Vseeno obstajajo nekatere raziskave, $v$ katerih so avtorji preučevali različne motive kmetov za (ne)sodelovanje v shemah SKP, na primer v primeru kmetijsko-okoljskih plačil (KOP) (Ingram s sodelavci 2013;

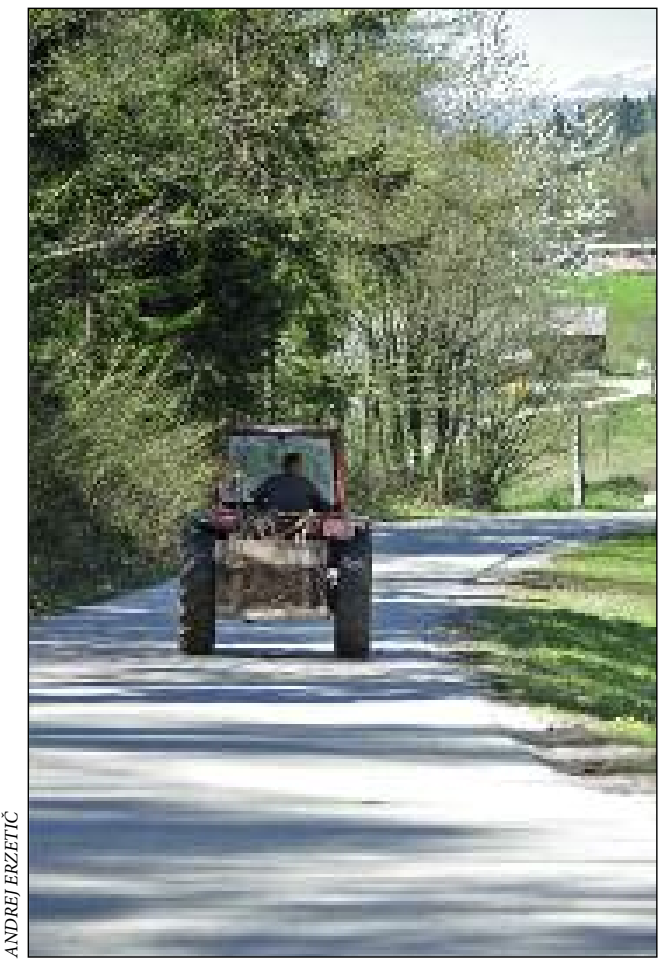

Slika 2: Le kmet lahko uresniči okoljevarstvene cilje SKP. 
Falconer 2000; Sattler in Nagel 2010; Gorton s sodelavci 2007; Van Herzele s sodelavci 2013). Namen KOP je popularizacija kmetijske pridelave, ki ustreza potrebam potrošnikov ter varuje zdravje ljudi, zagotavlja trajnostno rabo naravnih virov in omogoča zmanjševanje negativnih vplivov kmetijstva na okolje. KOP spodbujajo ohranjanje naravnih danosti, biotske pestrosti, rodovitnosti prsti in tradicionalne kulturne pokrajine ter varujejo zavarovana območja (Medmrežje 6). Raziskave, ki se sicer nekoliko razlikujejo glede uporabljene metodologije in rezultatov, ločujejo različne skupine kmetov, ki se med seboj ločijo glede na to, v kolikšni meri so v resnici predani cilju trajnostnega razvoja podeželja oziroma izvajanju okoljskih ukrepov. Vse ugotavljajo, da obstaja določen delež kmetov, ki varovanju okolja ne pripisujejo velikega pomena, da določen delež kmetov vstopa v shemo KOP zaradi zaslužka, ter da relativno majhen delež kmetov čuti odgovornost varovati okolje in prispevati k trajnostnemu razvoju podeželja.

Pomanjkanje zaupanja v institucije in politike EU je že dolgo prepoznan izziv, ki pa ga EU za zdaj še ni uspela rešiti. Že leta 2001 je Evropska komisija izdala Belo knjigo o evropskem upravljanju (European ... 2001), kjer ugotavlja, da je v EU prisoten paradoks: na eni strani prebivalci EU pričakujejo, da bo EU našla rešitve za glavne probleme, s katerimi se sooča evropska družba, po drugi strani pa je v družbi zaznati vedno večje nezaupanje v institucije in vodenje EU ter celo popolno nezanimanje za evropsko politiko. Evropska komisija ugotavlja, da je EU na eni strani ljudem preveč oddaljena, nejasna, po drugi pa preveč vsiljena. Rešitev, ki jo je Evropska komisija predlagala v Beli knjigi, je takojšnje ukrepanje na področju upravljanja EU v smeri večjega vključevanja prebivalcev oziroma javnosti v odločanje in sprejemanje politik. Tako naj bi EU postala bolj odprta, jasna in sprejemljiva za javnost (European ... 2001).

Na potrebo po spremembi upravljavskih sistemov, ki bi bolje povezali znanost (stroko), nosilce odločanja in javnost ter tako pripomogli k večji legitimnosti vodenja in oblikovanja politik, opozarjajo tudi nekateri sociologi (Beck 1992; 2004; Wynne 1996), ki se ukvarjajo s področjem participacije v postopkih odločanja in oblikovanja politik (Jasanoff 2003).

Legitimnost je lastnost neke avtoritete, institucije ali družbene ureditve, zaradi katere družba vanjo verjame ter jo dojema kot primerno in pravilno. Če družba neko avtoriteto, institucijo ali družbeno ureditev dojema kot legitimno, ljudje verjamejo, da lahko vplivajo na odločitve in pravila, ki jih nato upoštevajo prostovoljno, na podlagi občutka zavezanosti in ne zaradi strahu pred kaznijo ali pričakovanja nagrade (Tyler 2006). Koncept legitimnosti je večplasten in vključuje dejavnike, kot so pravičnost, lastni interesi družbe ter njene skupne vrednote in norme (Suchman 1995; Hechter 2009).

Ko govorimo o politikah in njihovi legitimnosti, moramo opozoriti zlasti na tri vidike (Bréhon 2011): - Ali ima politika trdne temelje?

- Ali so cilji politike splošno sprejeti v družbi?

- Ali je dosežena trajna podpora politiki?

Bréchon (2011) SKP očita, da je z leti postala manj politična, manj skupna (sheme se med državami razlikujejo), predvsem pa manj kmetijska (danes je postal glavni cilj SKP razvoj podeželja, ki pa nima neposredne povezave s poglavitno nalogo kmetijstva, pridelavo hrane). Avtor opozarja na to, da so zaradi pomanjkanja legitimnosti postali prav kmetje, ki so tako rekoč njeni glavni uporabniki, najbolj kritični do SKP.

Kljub sredstvom, ki jih SKP namenja kmetijstvu in razvoju podeželja, določena območja, predvsem slabše dostopna, manj razvita in obmejna, nazadujejo. Soočajo se z odseljevanjem in opuščanjem kmetijstva, pokrajina ostaja neobdelana, prihaja do zaraščanja, značilne kulturne pokrajine pa zato izginjajo. Na drugi strani je v območjih, ki so za kmetijstvo najugodnejša, še vedno prisotno intenzivno kmetijstvo. Kmetje torej ne sledijo slepo okoljevarstvenim ciljem SKP in ne sprejemajo povsem dodeljene vloge upravljavcev pokrajine, saj stremijo predvsem k izpolnitvi interesov po konkurenčnosti in zaslužku. 


\section{Možnosti izboljšanja legitimnosti politik v postopkih odločanja}

Mnoge kritike SKP izhajajo iz pomanjkanja njene legitimnosti - torej iz dejstva, da evropski kmetje ne sprejemajo slepo vloge upravljavcev podeželja, s čimer bi pripomogli k doseganju cilja trajnostnega razvoja. Ne preseneča torej, da se na področju usmerjanja prostorskega razvoja vedno bolj uveljavlja tako imenovano participativno planiranje. Gre za premoščanje posameznih interesov ter usmeritev k partnerstvu in skupnemu upravljanju. Nove razvojne politike naj bi torej težile k razvoju družbenega kapitala in k vključevanju čim širšega kroga deležnikov v procese planiranja (Nared in Razpotnik Visković 2014). Vključevanje participativnega procesa v postopke oblikovanja politik je tudi eden ključnih dejavnikov pri doseganju trajnostnega razvoja (Nared, Erhartič in Razpotnik Visković 2013). Tak način prostorskega planiranja predpostavlja nastajanje novih institucij in prenovo obstoječih. Pri tem se težko izognemo ideološkim, političnim in gospodarskim vprašanjem, zaradi katerih lahko pride tudi do napetosti med različnimi resorji in ravnmi odločanja. Kljub temu je takšna oblika planiranja, ki predpostavlja prerazporeditev pristojnosti in odpiranje odločevalskih planerskih postopkov vsem zainteresiranim deležnikom, v sodobnih razmerah edina učinkovita planerska usmeritev (Kos 2003).

Na potrebo po preoblikovanju načina oblikovanja razvojnih in prostorskih politik, kakršna je SKP, opozarja tudi Jasanoffova (2003). Avtorica zagovarja nujno povezavo med strokovnjaki, nosilci odločanja in javnostjo, kar je nepogrešljivo za uspešnost sodobnega načina upravljanja. V evropskem prostoru ni prave tradicije participacije pri sprejemanju politik; čeprav EU počasi uvaja tudi takšne vrste sodelovanja, spremembe še niso zadostne, da bi se prebivalci lahko z njimi zadovoljili, oziroma da bi povečale raven legitimnosti evropskih politik (Jasanoff 2003).

\section{Sklep}

SKP se je spremenila iz izrazito sektorske kmetijske politike v prostorsko (podeželsko) politiko (McDonagh 2012). Spremembe so bile tako vsebinske kot strukturne. Začetno spodbujanje produktivnosti v kmetijstvu EU je povzročilo presežke določenih kmetijskih pridelkov, negativne okoljske posledice zaradi intenzivnosti kmetijstva, hkrati pa je tak sistem tudi močno obremenjeval proračun SKP. Skladno s svetovnimi trendi se je tudi v SKP počasi začelo uveljavljati načelo trajnosti. Do danes sta postala skrb za okolje in trajnostni razvoj podeželja dva izmed temeljnih ciljev SKP. V primerjavi z začetki se je močno spremenila tudi sama struktura pomoči kmetom. Plačila, ki jih je EU sprva izplačevala kmetom glede na količino pridelane hrane in ki so močno spodbudila intenzivnost kmetijske proizvodnje, so danes razdeljena v dva tako imenovana stebra. Prvega sestavljajo neposredna plačila, vezana na hektar kmetijskih zemljišč, drugega pa sredstva, namenjena razvoju podeželja. V obeh stebrih je močno prisoten normativni cilj trajnostnega razvoja podeželja.

SKP temelji na prostovoljnem sodelovanju kmetov, kar pomeni, da se sami odločajo, katere ukrepe bodo upoštevali (če sploh) in v kolikšni meri bodo upoštevali okoljska določila. Njihove odločitve so odvisne tako od okoljske zavesti kot tudi od ovir, motivacije in navad. Kljub temu da SKP kmetom pripisuje glavno odgovornost za ohranjanje kmetijstva, doseganje okoljskih ciljev in trajnostni razvoj podeželja, se pogosto izkaže, da obstaja le določen, relativno majhen delež kmetov, ki dejansko čutijo moralno odgovornost varovati okolje in prispevati k trajnostnemu razvoju podeželja.

Šibka predanost kmetov okoljskim ciljem SKP, opuščanje kmetijstva in izgubljanje značilnih evropskih kulturnih pokrajin (kljub finančnim spodbudam), kažejo na pomanjkanje legitimnosti politike.

Številni avtorji, kot rešitev za povečanje legitimnosti SKP in prostorskega razvoja, predlagajo vključevanje participativnega procesa v postopke oblikovanja politik. S premoščanjem posameznih interesov, partnerstvom, razvojem družbenega kapitala ter z vključevanjem čim širšega kroga deležnikov v postopke planiranja, bi lahko dosegli večjo legitimnost politik in uspešnost pri doseganju trajnostnega razvoja. 
Maruša Goluža $\quad$ Vprašanje legitimnosti skupne kmetijske politike z vidika okoljske komponente ...

Zahvala: Članek je rezultat raziskovalnega dela v okviru doktorskega študija, ki sta ga sofinancirali Evropska unija (Evropski socialni sklad) ter Ministrstvo za izobraževanje, znanost in šport Republike Slovenije v okviru Operativnega programa razvoja človeških virov v obdobju 2007-2013.

\section{Viri in literatura}

Agenda 2000, For a Stronger and Wider Europe, 1997. Medmrežje: http://www.ab.gov.tr/files/ardb/evt/ 2_turkiye_ab_iliskileri/2_1_ortaklik_iliskileri/2_1_4_diger/gundem_2000_eng.pdf (22.6.2014).

Agenda 21. Združeni narodi. 1992. Medmrežje: http://sustainabledevelopment.un.org/content/ documents/Agenda21.pdf (22.6.2014).

Agricultural Policy Perspective Briefs. 2011. Medmrežje: http://ec.europa.eu/agriculture/policyperspectives/policy-briefs/01_en.pdf (2.7.2014).

Amsterdamska pogodba. 1999. Medmrežje: http://www.evropa.gov.si/fileadmin/dokumenti/ dokumenti/EU/Pravni_red/amsterdam.pdf (22.6.2014).

Baldock, D., Dwyer, J., Sumpsi Vinas, J. M. 2002: Environmental Integration and the CAP, A Report to the European Commission. Medmrežje: http://ec.europa.eu/agriculture/envir/report/ieep_en.pdf (22.6. 2014).

Beck, U. 1992: Risk Society, Towards a New Modernity. London.

Beck, U. 2004: The Truth of Others, A Cosmopolitan Approach. Common Knowledge 10-3. Oxford. DOI: $10.1215 / 0961754 \mathrm{X}-10-3-430$

Becker, C. U. 2012: Sustainability Ethics and Sustainability Research. DOI: 10.1007/978-94-007-2285-9_1

Bréhon, N. J. 2011: The CAP on the quest for legitimacy. European Issue 209. Medmrežje: http://www.robert-schuman.eu/en/doc/questions-d-europe/qe-209-en.pdf (22.6. 2014).

CAP Reform Summary. 2003. Medmrežje: http://ec.europa.eu/agriculture/mtr/sum_en.pdf (22.6. 2014).

Enotni evropski akt. 1987. Medmrežje: http://www.evropa.gov.si/fileadmin/dokumenti/dokumenti/ EU/Pravni_red/enotni-evropski-akt.pdf (22.6.2014).

European Governance, A White Paper. 2001. Medmrežje: http://eur-lex.europa.eu/legal-content/EN/TXT/ PDF/?uri=CELEX:52001DC0428\&rid=2 (22.6.2014).

European Union Guidelines for State Aid in the Agriculture and Forestry Sector and in Rural Areas 2014 to 2020. 2014. Medmrežje: http://ec.europa.eu/agriculture/stateaid/policy/feedback-gl/ draft-gl-2_en.pdf (22.6.2014).

Falconer, K. 2000: Farm-level constraints on agri-environmental scheme participation: a transactional perspective. Journal of Rural Studies 16-3. Oxford. DOI: 10.1016/S0743-0167(99)00066-2

Gorton, M., Douarin, E., Davidova, S., Latruffe, L. 2008: Attitudes to agricultural policy and farming futures in the context of the 2003 cap reform: a comparison of farmers in selected established and new member states. Journal of Rural Studies 24-3. Oxford. DOI: 10.1016/j.jrurstud.2007.10.001

Hechter, M. 2009: Legitimacy in the Modern World. American Behavioral Scientist 53-3. Princeton. DOI: $10.1177 / 0002764209338793$

Ingram, J., Gaskell, P., Mills, J., Short, C. 2013: Incorporating agri-environment schemes into farm development pathways: A temporal analysis of farmer motivations. Land Use Policy 31. Guildford. DOI: 10.1016/j.landusepol.2012.07.007

Jasanoff, S. 2003: Technologies of humility: citizen participation in governance science. Minerva 41-3. Dordrecht. DOI: 10.1023/A:1025557512320

Johannesburg Declaration on Sustainable Development. Združeni narodi. 2002. Medmrežje: http://www.un-documents.net/jburgdec.htm (22.6.2014).

Kos, D. 2003: Postmoderno prostorsko planiranje? Teorija in praksa 40-4. Ljubljana.

McDonagh, J. 2012: Rural geography I, Changing expectations and contradictions in the rural. Progress in Human Geography 37-5. London. DOI: 10.1177/0309132512474404 
Medmrežje 1: http://europa.eu/about-eu/eu-history/index_sl.htm (22.6.2014).

Medmrežje 2: http://ec.europa.eu/agriculture/cap-history/early-years/index_en.htm (22.6.2014).

Medmrežje 3: http://ec.europa.eu/agriculture/cap-history/crisis-years-1970s/index_en.htm (22.6.2014).

Medmrežje 4: http://ec.europa.eu/agriculture/cap-history/crisis-years-1980s/index_en.htm (22.6.2014).

Medmrežje 5: http://ec.europa.eu/agriculture/cap-history/1992-reform/index_en.htm (22.6.2014).

Medmrežje 6: http://www.arsktrp.gov.si/si/storitve_ukrepi/ukrepi_razvoja_podezelja/ohranjanje_ okolja_in_podezelja/kmetijsko_okoljska_placila_kop/ (22.6.2014).

Nared, J., Razpotnik Visković, N. (ur.) 2014: Managing Cultural Heritage Sites in Southeastern Europe. Ljubljana.

Nared, J., Erhartič, B., Razpotnik Visković, N. 2013: Including development topics in a cultural heritage management plan, mercury heritage in Idrija. Acta Geographica Slovenica 53-2. Ljubljana. DOI: 10.3986/AGS53404

Perspectives of the Common Agricultural Policy, Communication of the Commission to the Council and the Parliament. 1985. Medmrežje: http://ec.europa.eu/green-papers/pdf/green_paper_perspectives_for_cap_com_85_333.pdf (22.6.2014).

Petrick, M. 2008: The co-evolution of semantics and policy paradigms: 50 years of europe's common agricultural policy. Intereconomics 43-4. Hamburg. DOI: 10.1007/s10272-008-0257-8

Plut, D. 2010: Geografija sonaravnega razvoja. Ljubljana.

Pogodba o Evropski uniji. 1993. Medmrežje: http://www.evropa.gov.si/fileadmin/dokumenti/dokumenti/ EU/Pravni_red/maastricht.pdf (22.6.2014).

Reform of the Common Agricultural Policy. 1991. Medmrežje: http://ec.europa.eu/agriculture/cap-history/ 1992-reform/com91-379_en.pdf (22.6.2014).

Polajnar Horvat, K. 2012: Oblikovanje modela razvoja okoljske ozaveščenosti in okolju prijaznega vedenja. Geografski vestnik 84-2. Ljubljana.

Promoting Europe's Agriculture and Rural Areas, Continuity and Change. 1998. Medmrežje: http://bookshop.europa.eu/en/the-common-agricultural-policy-pbCH1097970/ (22.6. 2014).

Report of the World Commission on Environment and Development, Our Common Future. Združeni narodi. 1987. Medmrežje: http://www.un-documents.net/wced-ocf.htm (22.6.2014).

Sattler, C., Nagel, U. J. 2010: Factors affecting farmers' acceptance of conservation measures: A case study from North-eastern Germany. Land Use Policy 27-1. Guildford. DOI: 10.1016/ j.landusepol.2008.02.002

Suchman, M. C. 1995: Managing legitimacy, strategic and institutional approaches. Academy of Management Review 20-3. DOI: 10.5465/AMR.1995.9508080331

The Development and Future of the CAP. 1991. Medmrežje: http://ec.europa.eu/agriculture/cap-history/ 1992-reform/com91-100_en.pdf (22.6.2014).

The Future of Rural Society. 1988. Medmrežje: http://ec.europa.eu/agriculture/cap-history/ crisis-years-1980s/com88-501_en.pdf (22.6.2014).

The Rio Declaration on Environment and Development. 1992. Medmrežje: http://www.unesco.org/ education/nfsunesco/pdf/RIO_E.PDF (22.6.2014).

The Treaty of Rome. 1957. Medmrežje: http://ec.europa.eu/archives/emu_history/documents/treaties/ rometreaty2.pdf (22.6.2014).

Towards a Common Agricultural and Rural Policy for Europe. 1997. Medmrežje: http://ec.europa.eu/ agriculture/publi/buck_en/index.htm (22.6.2014).

Tyler, T. R. 2006: Psychological perspectives on legitimacy and legitimation. Annual Review of Psychology 57. Stanford. DOI: 10.1146/annurev.psych.57.102904.190038

Van Herzele, A., Van Gossum, P., Gobin, A., Acosta, L., Waas, T., Dendoncker, N., de Frahan, B. H. 2013: Effort for money? Farmers' rationale for participation in agri-environment measures with different implementation complexity. Journal of Environmental Management 131. London. DOI: 10.1016/ j.jenvman.2013.09.030 
Vrevc, S. 2011: Skupna kmetijska politika do 2020, Glavni elementi zakonodajnih predlogov. Medmrežje: http://www.kgzs.si/Portals/0/Dokumenti/izobrazevanja/01\%20Vrevc.pdf (22. 6. 2014).

Wynne, B. 1996: May the sheep safely graze? A reflexive view of the expert-lay knowledge devide. Risk, Environment and Modernity: Towards a New Ecology. London. DOI: 10.4135/9781446221983

\section{Summary: The issue of CAP legitimacy in terms of the environmental component of sustainable rural development}

(translated by the author)

Since its implementation, the common European agricultural policy (CAP) has considerably changed from prevailingly sectoral, agricultural, to predominantly spatial, rural policy (McDonagh 2012). These changes affected both, content and structure of the policy. Initial encouraging of agricultural production had led to the intensification of agricultural production, causing negative environmental consequences. The CAP had also represented increasing financial burden for the European budget. Over time, the CAP has followed the global trends and gradually adopted the principle of sustainable development. The first document, which indicated radical changes in the CAP, was the so-called Buckwell report (Towards ... 1997). It suggested that the CAP should endeavour to balance the three key principles: an efficient agriculture, environmental sustainability and rural development. Furthermore, the report also advocated the idea that financial measures should be completely independent of agricultural productivity (Towards ... 1997). With The Treaty of Amsterdam (1999) the CAP finally adopted the principle of sustainable development that brought together economic, social and environmental objectives. The second pillar of the CAP, funding the measures aiming at sustainable rural development was also established (Promoting ... 1998).

The 2003 CAP reform, that followed, brought four major changes (CAP ... 2003):

- The single payment scheme decoupled of what farmers produced. A major aim of the single payment scheme was to allow farmers to become more market oriented and to release their entrepreneurial potential.

- Compulsory cross-compliance; a 'priority list' of 18 statutory European standards in the fields of environment, food safety, and animal health and welfare was established. For non-respect of these standards farmers would be sanctioned through cuts in direct payments.

- Modulation or reallocation of resources in favour of the CAP rural development measures.

- Strengthened rural development policy; a significant extension of the scope of instruments for rural development, starting in 2005, to promote food quality, meet higher standards and foster animal welfare.

Nowadays, the emphasis on sustainable rural development is recognizable in both, the first and the second pillar of the CAP. In the upcoming programming period from 2014 to 2020, the amount of direct payments in the first pillar will be even more dependent on the cross-compliance (Vrevc 2011).

The CAP is based on a farmers' voluntary participation and their personal decisions. It means that their choices about which environmental measures of the CAP (if any at all) they will perform are entirely determined by farmers' personal decisions. Their behaviour is strongly dependent on farmers' environmental awareness, hinders, motivation and habits (Polajnar Horvat 2012). According to the CAP, farmers are considered to be responsible for the conservation of agriculture and nature, and for accomplishing the goals of sustainable rural development. Nevertheless, several studies indicate a relatively limited share of farmers whose decisions to implement environmentally friendly agricultural practices are made solely on the basis of their moral duty to contribute to the sustainable rural development (e.g., Falconer 2000; Gorton et al. 2008; Sattler and Nagel 2010; Ingram et al. 2013; Van Herzele et al. 2013). Despite financial incentives, weak commitment to environmental goals of the CAP, abandonment of agricultural practice and the loss of characteristic European cultural landscapes implies that the policy lacks legitimacy. 
Legitimacy is a psychological property of an authority, institution, or social arrangement that leads those connected to it to believe that it is appropriate, proper, and just. Because of legitimacy, people feel that they ought to defer to decisions and rules, following them voluntarily out of obligation rather than out of fear of punishment or anticipation of reward (Tyler 2006). Bréchon (2011) claims that the CAP has become less political, less common (the support schemes are different from state to state) and less agricultural (rural development is a patchwork, mixing rural matters, environment and social aid, but there is no link to agricultural production). Farmers, the main beneficiaries of the CAP have thus become the most hostile to the CAP (Bréchon 2011).

The lack of trust in the European institutions and policies has already been recognized by the EU, but not yet solved. In 2001 the EU published the so called White Paper on European governance which exposes a paradox. On the one hand, European citizens expect politicians to find solutions to the major problems confronting societies. On the other hand, people increasingly distrust institutions and politics or are simply not interested in them. The EU is often seen as remote and at the same time too intrusive. The White Paper proposes opening up the policy-making process to get more people and organisations involved in shaping and delivering EU policy. It promotes greater openness, accountability and responsibility for all those involved (European ... 2001).

Not surprisingly, in the field of spatial development there is an increasing need for the so-called participatory planning. It encourages overcoming individual interests, partnership and joint management. New development policies should strive for the development of social capital and for the integration of as many stakeholders as possible in the planning process (Nared and Razpotnik Visković 2014). Integrating participatory process in the policy-making process is also one of the key factors for achieving the goal of sustainable development (Nared, Erhartič and Razpotnik Visković 2013). The collaboration between experts, decision-makers and the public is considered to be essential for the successful and legitimate governance. Despite participatory traditions are less thoroughly institutionalized in European policy-making, recent changes display a growing commitment to involving the public in technically-grounded decisions. Nevertheless, these changes are still not sufficient for the European citizens and have not raised the level of European policies' legitimacy considerably (Jasanoff 2003). 